\title{
ALOCUÇÃO DE SUA SANTIDADE O PAPA PAULO VI AS ENFERMEIRAS PARTICIPANTES DO X CONGRESSO MUNDIAL DO CICIAMS
}

Paiavras de Sua Santidade Paulo VI dirigidas às enfermeiras católicas do CICIAMS por ocasião da audiência especial que the concedeu quando da realização do X Congresso Mundial, em Roma, de 19 a 26 de Maio de 1974. A saudação foi feita em francês e reproduzicia em alemão, espanhol, inglês e italiano.

"Senhora Presidente e caras congressistas,

Para Nós, a vossa visita constitui motivo de especial alegria e esperança. Nesse quadragésimo aniversário da criação do CICIAMS, sois testemunhas de sua impressionante expansão, especialmente na África e na América Central. Por isso, cumprimentamos calorosamente as organizadoras deste segundo Congresso Mundial de Roma, c os quatro mil participantes, vindos de todos os países a fim de partilharem suas preciosas experiências no mundo hospitalar e de renovarem sua disposição de melhor serví-lo.

Nestes breves instantes rão mencionaremos as excelentes conferências e os debates animados que marcaram o vosso Congresso. Desejamos somente, no plano de nossas responsabilidades pastorais, apresentar-vos nosso mais vivo apoio.

Vossas dificuldades, de ordem pessoal ou profisisonal, ou próprias da situação dos países em que servem, estão presentes em nosso espírito. Portanto, para vós, mais do que nunca, desejamos o dom do entusiasmo, um entusiasmo cristão e realista. Sem minimizar a necessidade de um aperfeiçoamento profissional permanente, permitimo-nos insistir sobre a urgência de cultivardes as vossas convicções moraes e espirituais. pelo fundamental e apaixonante motivo de vos encontrarojes sempre em contato com realidades sagradas. Quer se trate de crianças por nascer ou de velhos, de acidentados ou enfermos, de defeituosos físicos ou mentais, trata-se sempre do homem, sobre quem estas nobres palavras estão inscritas nas pri- 
meiras páginas da Bíblia: "Deus criou o homem à sua imagem" (Gen. 1, 27). Inúmeras vezes já foi dito que uma civilização pode ser julgada pela sua conduta em relação aos fracos, às crianças, aos enfermos, às pessoas da terceira idade.

Fortificadas por vossas convicções, desenvolvidas pelo esforço individual e com o auxílio das Associações locais ou regionais, continuai o trabalho pela expansão, em vossos países, duma "política sanitária" autêntica e humana. Trabalhai pela humanização da política sanitária. O hospital deve permanecer ou tornar-se o local humano por excelência, onde cada qual é tratado com dignidade; onde sente, apezar do sofrimento, a presença e a proximidade de irmãos, irmãs, amigos. Os sentimentos de humanidade não podem ser separados da assistência hospitalar. Participais desse encontro necessário entre a técnica e a espiritualidade, fora do qual o mundo moderno nada pode oferecer a não ser o desvario e a inquietude, pela aceleração de suas experiências, ou engendrar a fria monotonia duma existência programada, reduzida ao automatismo de um robot. Nos vos pertence, queridas filhas, o privilégio de dar um sentido pessoal a esse relacionamento, mantendo-o em todos os setores marcados pela vossa presença?

Não se pode ignorar, todavia, que o esforço apostólico de hoje, em ser verdadeira e plenamente eficiente no mundo profissional, exige organização e coordenação. Tal é a razão da existência das multiplas organizações às quais a Igreja dá tanta importância. Desejamos, portanto, exprimir nossa satisfação de vez que, no vosso domínio, haveis compreendido essa exigência e vos esforçais por agir sempre, não de maneira individual, mas em colaboração com aqueles que partilham do vosso ideal humano e cristão. Desejamos, pois, encorajar publicamente a atividade e o desenvolvimento de vossas Associações em todos os níveis, especialmente no plano nacional e internacional; a eficácia de vossas atividades depende em grande parte, estejais certas, desse desejo de união para oferecer melhor serviço.

A Igreja orgulha-se legitimamente da maravilhosa caridade de tantos fundadores e fundadoras de ordem hospitalares, de todos os que hoje trabalham seguindo o seu exemplo, das instituições que deixaram, da profissão que escolheram em seu devotamento à humanidade sofredora, assumindo esse papel pela fé. Pertenceis a esta Igreja, como leigas ou religiosas. Por isto, pedimos a Cristo, por vós e pelos que aqui representais, a graça de viverdes vossas responsabilidades, sempre delicadas e exigentes, com a força e a ternura das quais Ele nos deixou um exemplo perfeito.

Em Seu nome, nós vos abençoamos de todo o coração". 